\title{
Cheese yield, cheesemaking efficiency, and daily production of 6 breeds of goats
}

\author{
Giuseppe M. Vacca, ${ }^{*}$ Giorgia Stocco, ${ }^{* 1}$ Maria L. Dettori, ${ }^{*}$ Andrea Summer, $†$ Claudio Cipolat-Gotet, $\dagger$ \\ Giovanni Bittante, $\ddagger$ and Michele Pazzola* \\ *Department of Veterinary Medicine, University of Sassari, via Vienna 2, 07100 Sassari, Italy \\ †Department of Veterinary Science, University of Parma, Via del Taglio 10, 43126 Parma, Italy \\ †Department of Agronomy, Food, Natural resources, Animals and Environment (DAFNAE), University of Padova, viale dell'Università 16, \\ 35020 Legnaro (PD), Italy
}

\begin{abstract}
Little is known about the complex process of cheesemaking at the individual level of dairy goats because of the difficulties of producing a high number of model cheeses. The objectives of this work were (1) to study the cheesemaking ability of goat milk; (2) to investigate the variability of cheesemaking-related traits among different farms; (3) to assess the effects of stage of lactation and parity; and (4) to compare 6 breeds of goat (Saanen and Camosciata delle Alpi for the Alpine type; Murciano-Granadina, Maltese, Sarda and Sarda Primitiva for the Mediterranean type) for their cheesemaking ability. For each goat $(\mathrm{n}=560)$ we studied (1) 8 milk quality traits (fat, protein, total solids, casein, lactose, $\mathrm{pH}$, somatic cell score, and bacterial count); (2) 4 milk nutrient recovery traits (fat, protein, total solids, and energy) in curd; (3) 3 actual cheese yield traits (fresh cheese, cheese solids, and cheese water); (4) 2 theoretical cheese yield values (fresh cheese and cheese solids) and the related cheesemaking efficiencies; and (5) daily milk yield and 3 daily cheese yield traits (fresh cheese, cheese solids, and water retained in the curd). With respect to individual animal factors, farm was not particularly important for recovery traits or actual and theoretical cheese yield and estimates of efficiency, whereas it highly influenced daily productions. Parity of goats influenced daily cheese production, whereas DIM slightly affected recovery as well as percent and daily cheese yield traits. Breed was the most important source of variation for almost all cheesemaking traits. Compared with those of Alpine type, the 4 Mediterranean breeds had, on average, lower daily milk and cheese productions, greater actual and theoretical cheese yield,
\end{abstract}

Received January 15, 2018.

Accepted April 20, 2018.

${ }^{1}$ Corresponding author: giorgiastocco12@gmail.com and higher recovery of nutrients in the curd. Among Alpine type, Camosciata delle Alpi was characterized by greater nutrients recovery than Saanen. Within the 4 Mediterranean types, the 3 Italians produced much less milk per day, with much more fat and protein and greater recovery traits than the Murciano-Granadina, resulting in greater actual cheese yield. Within the Italian breeds, milk from Sarda and Sarda Primitiva was characterized by lower daily yields, higher protein and fat content, and greater recoveries of nutrients than Maltese goats. These results confirmed the potential of goat milk for cheese production and could be useful to give new possibilities and direction in breeding programs.

Key words: cheese, farm, fat recovery, protein recovery

\section{INTRODUCTION}

World production of goat milk ranks third, below cow and buffalo milk, and is mainly used to produce cheese (FAOSTAT, 2014). The percentage ratio between milk processed and cheese manufactured $(\mathbf{\%} \mathbf{C Y})$ is considered one of the most important attributes of milk affecting the profitability of dairy farmers (Emmons et al., 1993). Cheese yield relies first on the fat and protein (in particular casein) content of milk, and also on the technological properties of processed milk (Law and Tamine, 2010); these characteristics can influence the proportion of individual milk components recovered in the curd (\%REC) or lost in the whey, directly related to the overall efficiency of cheesemaking process (Banks, 2007).

The increasing demand for goat cheeses in recent decades, coupled with an increase of milk price, has stimulated new interest in the cheesemaking ability of goat milk and formulae predicting cheese yield on the basis of milk components were proposed (Zeng et al., 2007). The main problem with those formulae with regard to goat milk is the wide range of variation of its 
composition in relation to different breeds and dairy systems. On the other hand, information on direct measurements of \% CY in the literature is scarce for goat species, and most of the studies on cheesemaking ability have used goat bulk milk (Fekadu et al., 2005; Chen et al., 2010), because collection and processing of individual samples are very time-consuming and laborintensive.

Moreover, goat breeds have been shown to have strong effects on cheese yield, but again this information comes from studies using bulk milk from few groups of a small number of animals into individual experimental farms (Soryal et al., 2005; Herrera et al., 2010) or using mixed milk from different breeds (Guo et al., 2004; Kouniba et al., 2007). Therefore, in those cases, comparison of breeds may be affected by a lack of representativeness, by different individual factors (i.e., parity, stage of lactation), or by farm characteristics (i.e., management and feeding).

More information is recently available from a large survey on milk coagulation, curd firming, and syneresis properties of goat milk of different breeds (Pazzola et al., 2018; Vacca et al., 2018). The suitability of lactodynamography for testing large number of individual goats relies on the small volume of milk and the possibility to test several samples in a short period. Traditionally, lactodynamography does not provide direct measurement of \%CY and \%REC traits, but only reproduces first steps of the cheesemaking process (i.e., rennet addition, milk coagulation, curd firming). However, recent modifications of the analysis procedures proposed by Cipolat-Gotet et al. (2016a) permit to assessment of the phases during which the obtained small curds are cut, heated, and drained. That method has stimulated more interest on the use of lactodynamography, as coagulation analysis could be assessed simultaneously with the efficiency of cheesemaking process. With regard to sheep, Othmane et al. (2002a) proposed an individual laboratory cheese yield procedure using $10 \mathrm{~mL}$ of milk, allowing the simultaneous recording of $\% \mathrm{CY}$ of several samples (Othmane et al., 2002b).

To our best knowledge, no previous studies have processed a high number of goat milk samples to mimic the complex process of cheesemaking on a small-scale laboratory method, allowing the estimation of several cheesemaking traits. For these reasons, the present study was proposed in order (1) to study the cheesemaking ability of goat milk; (2) to investigate the variability among different farms; (3) to assess the effects of stage of lactation and parity; and (4) to compare 6 breeds of goat for their \%REC, actual and theoretical ( $\boldsymbol{T h}) \% \mathrm{CY}$, efficiency of cheese-making (Eff-\%CY), and daily productions of cheese (dCY).

\section{MATERIALS AND METHODS}

\section{Farm Characteristics and Milk Sampling}

A total of 560 goats from 35 farms located in Sardinia (Italy) were sampled (16 animals per farm). Six breeds were investigated, namely Saanen (Sa; 99 goats) and Camosciata delle Alpi (CA; 98 goats) for the Alpine type, and Murciano-Granadina (MG; 89 goats), Maltese (Ma; 104 goats), Sarda (Sr; 86 goats), and Sarda Primitiva (SP; 84 goats) for the Mediterranean type. Details of the milk sampling and analysis have been described by Vacca et al. (2018), and environmental context and farming systems involved have been reported in Vacca et al. (2016).

\section{Analysis of Milk Traits}

Immediately after collection, individual milk samples were stored at $4^{\circ} \mathrm{C}$, analyzed, and processed within $24 \mathrm{~h}$ of sampling. All samples were analyzed for fat, protein, TS, casein, lactose, and pH with a MilkoScan FT6000 infrared analyzer (Foss Electric A/S, Hillerød, Denmark) calibrated in accordance with the related reference methods [ISO-IDF (2013) for fat, protein, casein, lactose and pH; ISO-IDF (2010) for TS]. Casein index was calculated as the casein-to-protein ratio. Somatic cell count was determined by a Fossomatic 5000 somatic cell counter (Foss Electric A/S) and transformed into the logarithmic SCS $\left[\log _{2}\left(\mathrm{SCC} \times 10^{-5}\right)+3\right]$. Total bacterial count was determined using a BactoScan FC150 analyzer (Foss Electric A/S) and transformed into the logarithmic bacterial count $\left[\mathbf{L B C} ; \log _{10}\right.$ (total bacterial count/1,000)].

\section{Individual Cheesemaking Procedure}

The 9-mL milk cheesemaking assessment proposed by Cipolat-Gotet et al. (2016a) was used to measure actual \%CY and \%REC traits. The following procedure was performed on 560 individual goat milk samples, with 2 replicates per each animal $(9 \mathrm{~mL} \times 2)$, for a total of 1,120 observations.

Briefly, each milk replicate was poured into a glass tube $(9 \mathrm{~mL})$, inserted into the modified sample rack of the lactodynamograph instrument, heated to $35^{\circ} \mathrm{C}$ for $15 \mathrm{~min}$, and mixed with $0.2 \mathrm{~mL}$ of a rennet solution [Hansen Standard 215, with $80 \pm 5 \%$ chymosin and $20 \pm 5 \%$ pepsin; 215 international milk clotting units/ $\mathrm{mL}$ (Pacovis Amrein AG, Bern, Switzerland); diluted to $1.2 \%$ (wt/vol) in distilled water]. The sample rack was then transferred from the heater to the lactodynamograph for a 30 -min duration test at $35^{\circ} \mathrm{C}$. At the end 
of the analysis, coagulated milk samples were manually cut using a stainless steel spatula, and the rack was moved to the heater for the 30-min curd-cooking phase $\left(55^{\circ} \mathrm{C}\right)$. In the middle of the cooking phase, each sample was subjected to a further manual cutting by the same operator. At the end, each glass tube was removed from the sample rack and the curd was separated from the whey. The curd was slightly pressed to facilitate the whey expulsion, and the curd was then suspended above the whey for $15 \mathrm{~min}$ at room temperature to favor the draining. The obtained curd and whey were weighed using a precision scale. As the volume of whey produced from a single vat (about $7.5 \mathrm{~mL}$ ) was not sufficient for assessment of the chemical composition using an infrared spectrophotometer (MilkoScan FT2, Foss Electric), 2 replicates of each milk sample were analyzed in 2 consecutive glass tubes of the same sample rack and the whey was pooled for chemical analysis. The weights of the milk, curd, and whey (in grams) and the chemical composition of milk and whey permitted us to estimate curd composition. The actual \%CY traits were $\mathbf{\% C Y}_{\mathrm{CURD}}, \mathbf{\%} \mathbf{C} \mathbf{Y}_{\text {SOLIDS }}$, and $\mathbf{\%} \mathbf{C Y}_{\mathrm{WATER}}$, calculated as the ratio of the weight $(\mathrm{g})$ of fresh curd, curd DM, and water retained in curd, respectively, to the weight of the milk processed (g) and multiplied by 100. Daily cheese yields $\left(\mathbf{d} \mathbf{C} \mathbf{Y}_{\mathbf{C U R D}}, \mathbf{d C Y}_{\text {SOLIDS }}\right.$, and $\mathbf{d C Y}_{\text {WATER }} ; \mathrm{kg} / \mathrm{d}$ ) were calculated by multiplying the different $\% \mathrm{CY}\left(\% \mathrm{CY}_{\mathrm{CURD}}, \% \mathrm{CY}_{\text {SOLIDS }}\right.$, and $\% \mathrm{CY}_{\text {WATER }}$, respectively) by the daily milk yield (dMY, kg/d), recorded as the total yield of morning plus afternoon milking. The \%REC traits were \%REC PROTEIN $_{\text {, }}$ $\% \mathbf{R E C}_{\mathrm{FAT}}$, and $\% \mathbf{R E C}_{\text {SOLIDS }}$, calculated as the ratio of the weight $(\mathrm{g})$ of the curd components (protein, fat, and DM, respectively) to the same component of milk (g) and multiplied by 100. Recovery of energy in the curd (\% $\left.\mathbf{R E C} \mathbf{C}_{\text {ENERGY }}\right)$ was calculated by estimating energy of milk and curd using an equation proposed by the NRC (2001), converted to megajoules per kilogram and multiplied by 100 .

\section{Definition of Cheesemaking Efficiency}

The $T h-\% \mathrm{CY}_{\mathrm{CURD}}$ of the milk samples of each goat was estimated using the formula of Van Slyke and Price (1949) reported by Emmons and Modler (2010) in their review:

$$
\begin{gathered}
\text { Th }-\% \mathrm{CY}_{\mathrm{CURD}}=(0.93 \times \% \text { fat }+\% \text { casein }-0.1) \\
\times 1.09 /[(100-\% \mathrm{M}) / 100]
\end{gathered}
$$

where 1.09 represents correction for milk minerals and cheese salt and carbohydrates, and \%M is the percentage moisture of cheese $(100-\%$ TS $)$.
A formula for estimating Th- $\% \mathrm{CY}_{\text {SOLIDS }}$ was derived from the previous one by deleting the last part, which corrects for cheese moisture:

$$
\begin{gathered}
T h-\% \mathrm{CY}_{\text {SOLIDS }}= \\
(0.93 \times \% \text { fat }+\% \text { casein }-0.1) \times 1.09 .
\end{gathered}
$$

The Eff- $\% \mathrm{CY}_{\text {CURD }}$ and Eff-\% $\mathrm{CY}_{\text {SOLIDS }}$ were calculated by expressing the experimental value in relation to the corresponding theoretical value for each goat:

$$
\begin{gathered}
E f f-\% \mathrm{CY}_{\mathrm{CURD}}=\% \mathrm{CY}_{\mathrm{CURD}} / T h-\% \mathrm{CY}_{\mathrm{CURD}} \text {, and } \\
E f f-\% \mathrm{CY} Y_{\text {SOLIDS }}=\% \mathrm{CY}_{\text {SOLIDS }} / T h-\% \mathrm{CY} \text { SOLIDS }
\end{gathered}
$$

\section{Statistical Analysis}

Experimental data from cheesemaking procedure $(2$ replicates per goat) were analyzed using the MIXED procedure (SAS Institute Inc., Cary, NC), according to the models

$$
\begin{aligned}
\mathrm{y}_{\text {lmnopq }} & =\mu+\text { Farm }_{\mathrm{l}}+\text { Breed }_{\mathrm{m}}+\text { Parity }_{\mathrm{n}}+\text { DIM }_{\mathrm{o}} \\
& + \text { Animal }_{\mathrm{p}}+\text { Glass tube }_{\mathrm{q}}+\mathrm{e}_{\text {lmnopq }},
\end{aligned}
$$

where $\mathrm{y}_{\text {lmnopq }}$ is the observed trait (\%CY, \%REC, Eff-\%CY, dCY traits); $\mu$ is the overall intercept of the model; Farm ${ }_{1}$ is the random effect of the lth farm $(1=$ 1 to 35); Breed $_{\mathrm{m}}$ is the fixed effect of the mth breed ( $\mathrm{m}$ $=\mathrm{Sa}, \mathrm{CA}, \mathrm{MG}, \mathrm{Ma}, \mathrm{Sr}$, and SP); Parity ${ }_{\mathrm{n}}$ is the fixed effect of the nth parity $[\mathrm{n}=1$ to 3 ; class $1=1$ st and 2nd (193 goats); class $2=3 \mathrm{rd}$ and 4 th (205 goats); class $3=5$ th or greater (162 goats)]; $\mathrm{DIM}_{\mathrm{o}}$ is the fixed effect of the oth class of DIM $[\mathrm{o}=1$ to 4 ; class $1=<80$ d (146 goats); class $2=81-120$ d (157 goats); class $3=$ $121-160$ d (157 goats); class $4=>160$ d (100 goats)]; Animal $_{\mathrm{p}}$ is the random effect of the pth animal $(\mathrm{p}=1$ to 560); Glass tube ${ }_{\mathrm{q}}$ is the random effect of the qth tube $(\mathrm{q}=1$ to 8$) ; \mathrm{e}_{\text {lmnopq }}$ is the random residual $\sim N\left(0, \sigma_{e}^{2}\right)$, where $\sigma=$ standard deviation. The effects of breed, parity, and DIM were tested using the random animal as the error line.

The $T h-\% \mathrm{CY}_{\mathrm{CURD}}, T h-\% \mathrm{CY}_{\mathrm{SOLIDS}}, \mathrm{dMY}$, and chemical components (fat, protein, TS, casein, lactose, $\mathrm{pH}$, SCS, and LBC) of milk samples were analyzed using a new model [2], obtained from [1], without the random factors of the animal and the glass tube.

Orthogonal contrasts were estimated between least squares means of traits for breed effects. Specifically, (1) Alpine ( $\mathrm{Sa}$ and $\mathrm{CA}$ ) versus Mediterranean type breeds (MG, Ma, Sr, and SP); (2) between the 2 Alpine 
breeds (Sa vs. CA); (3) within the 4 Mediterranean, comparing the Spanish to Italian breeds (MG vs. Ma, $\mathrm{Sr}$ and SP); (4) within the 3 Italian breeds, comparing Ma, from Sicily, with $\mathrm{Sr}$ and SP, from Sardinia; and (5) comparing the 2 breeds from Sardinia ( $\mathrm{Sr}$ vs. SP). Moreover, orthogonal contrasts were estimated between least squares means of traits for parity effect, specifically (1) 1 st and 2 nd versus $\geq 3 \mathrm{rd}$, and (2) $3 \mathrm{rd}$ and 4 th versus $\geq 5$ th, and for DIM, specifically linear, quadratic, and cubic pattern.

A further model [3] was then used to analyze the direct effects of breed on cheesemaking traits corrected for dMY and quality traits and was obtained from model [1] with inclusion of linear covariates of dMY, fat, protein, TS, casein, lactose, $\mathrm{pH}$, SCS, and LBC. Moreover, the breed effect was considered random to obtain a correct quantification of the breed variance. The indirect effect of breed on cheesemaking traits due to breed differences in terms of dMY and quality was obtained by subtracting the breed variance estimated by model [3] from the breed variance resulting from base model [1] (with breed as random effect). Both direct and indirect breed variances were represented as a percentage of their sum.

\section{RESULTS}

\section{Effects of Farm and Animal}

Table 1 summarizes descriptive statistics of milk composition, \%REC, actual \%CY, Th-\%CY, Eff-\%CY, and $\mathrm{dCY}$. Almost all traits exhibited a normal distribution and, in the case of daily yield traits and hygienic measures, high variability.

Variances of the random effects for milk composition, daily productions, and cheesemaking traits are summarized in Table 2. Among chemical composition, the proportion of variance due to the farm was very large for LBC, followed by fat, $\mathrm{pH}$, and TS of milk, whereas the incidence of this effect on the other milk compo-

Table 1. Descriptive statistics of milk composition, daily productions, and cheesemaking traits of goat milk samples

\begin{tabular}{|c|c|c|c|c|c|}
\hline \multirow[b]{2}{*}{ Trait } & \multirow[b]{2}{*}{$\mathrm{N}$} & \multirow[b]{2}{*}{ Mean } & \multirow[b]{2}{*}{$\mathrm{CV}$} & \multicolumn{2}{|c|}{ Percentile } \\
\hline & & & & 1 st & 99th \\
\hline \multicolumn{6}{|c|}{ Milk composition } \\
\hline Fat, $\%$ & 558 & 4.59 & 32 & 2.23 & 9.28 \\
\hline Protein, \% & 558 & 3.59 & 15 & 2.68 & 4.98 \\
\hline Casein, \% & 558 & 2.82 & 18 & 1.96 & 4.20 \\
\hline Casein index ${ }^{1}$ & 558 & 0.78 & 4 & 0.70 & 0.86 \\
\hline Lactose, \% & 558 & 4.66 & 6 & 3.97 & 5.25 \\
\hline $\mathrm{TS}, \%$ & 558 & 13.74 & 14 & 10.81 & 19.21 \\
\hline $\mathrm{pH}$ & 554 & 6.72 & 2 & 6.47 & 6.99 \\
\hline $\mathrm{SCS}^{2}$ & 558 & 5.61 & 35 & 1.44 & 10.09 \\
\hline $\mathrm{LBC}^{3}$ & 557 & 1.80 & 46 & 0.30 & 3.95 \\
\hline \multicolumn{6}{|c|}{ Nutrient recovery (\%REC), \% } \\
\hline$\% \mathrm{REC}_{\mathrm{FAT}}$ & 1,110 & 80.5 & 8 & 60.45 & 90.49 \\
\hline$\%$ REC $_{\text {PROTEIN }}$ & 1,110 & 81.5 & 3 & 74.12 & 86.62 \\
\hline$\%$ REC $_{\text {SOLIDS }}$ & 1,110 & 55.7 & 10 & 43.70 & 67.06 \\
\hline$\% \mathrm{REC}_{\text {ENERGY }}$ & 1,110 & 66.3 & 9 & 52.72 & 76.70 \\
\hline \multicolumn{6}{|c|}{ Cheese yield (\%CY), \% } \\
\hline$\% \mathrm{CY}_{\mathrm{CURD}}$ & 1,102 & 15.7 & 20 & 10.31 & 22.93 \\
\hline$\% \mathrm{CY}_{\text {SOLIDS }}$ & 1,110 & 7.7 & 23 & 4.93 & 12.63 \\
\hline$\% \mathrm{CY}_{\text {WATER }}$ & 1,102 & 8.0 & 20 & 4.94 & 12.28 \\
\hline \multicolumn{6}{|c|}{ Theoretical (Th) \%CY } \\
\hline$T h-\% \mathrm{CY}_{\mathrm{CURD}}$ & 1,116 & 15.5 & 25 & 9.46 & 27.56 \\
\hline$T h-\% \mathrm{CY}_{\text {SOLIDS }}$ & 1,116 & 7.6 & 25 & 4.63 & 13.50 \\
\hline \multicolumn{6}{|c|}{ Cheesemaking efficiency (Eff), \% } \\
\hline Eff- $\% \mathrm{CY}_{\mathrm{CURD}}$ & 1,100 & 103 & 16 & 73 & 145 \\
\hline Eff- $\% \mathrm{CY}_{\text {SOLIDS }}$ & 1,114 & 102 & 6 & 86 & 120 \\
\hline \multicolumn{6}{|c|}{ Daily (d) production traits, $\mathrm{kg} / \mathrm{d}$} \\
\hline dMilk yield & 558 & 1.92 & 58 & 0.24 & 4.80 \\
\hline $\mathrm{dCY} \mathrm{CURD}_{\mathrm{C}}$ & 543 & 0.28 & 53 & 0.02 & 0.66 \\
\hline $\mathrm{dCY}_{\text {SOLIDS }}$ & 555 & 0.14 & 50 & 0.02 & 0.32 \\
\hline $\mathrm{dCY}_{\text {WATER }}$ & 544 & 0.15 & 57 & 0.02 & 0.37 \\
\hline
\end{tabular}

${ }^{1}$ Casein index: casein to protein ratio.

${ }^{2} \mathrm{SCS}=\log _{2}\left(\mathrm{SCC} \times 10^{-5}\right)+3$.

${ }^{3} \mathrm{LBC}=\log$ arithmic total bacterial count $=\log _{10}$ (total bacterial count $\left./ 1,000\right)$. 
nents was smaller $(28.8 \%$ for SCS content to $38.3 \%$ for casein content).

In the case of cheesemaking traits, farm was always lower than animal effect, varying from 19 to $46 \%$ of the total variance for $E f f-\% \mathrm{CY}_{\mathrm{CURD}}$ and $T h-\% \mathrm{CY} \mathrm{Y}_{\mathrm{CURD}}$, respectively, whereas the animal effect ranged from 49 to $83 \%$. Glass tube of the instrument sample rack had very little or no effect on the variability of the cheesemaking traits (from 0.0 to $0.13 \%$ of the total variance), highlighting the optimum repeatability of the method (from 78.5 to $99.9 \%$ for $\% \mathrm{CY}_{\mathrm{WATER}}$ and $\% \mathrm{REC}_{\mathrm{FAT}}$, respectively, data not shown). Farm and animal affected almost equally all daily production traits.

\section{Effect of Parity and DIM}

The least squares means of parity and related orthogonal contrasts on milk quality and cheesemaking traits are summarized in Table 3. Parity had a mod- est effect on the quality of milk and on cheesemaking traits, with the only exception of SCS and daily yields. Milk from goats in first and second parity had greater content of lactose and LBC and much lower SCS content than milk from goats with 3 or more parities. Although the differences in milk protein content across classes of parity were not significant, the recovery of protein from milk to cheese $\left(\% \mathrm{REC}_{\text {PRoтеIN }}\right)$ was greater in first- and second-parity goats and, in general, it was lower in goats with 5 or more parities. Among cheese yields traits, actual $\% \mathrm{CY}_{\mathrm{CURD}}$ was significantly lower in goats with 5 or more parities. As expected, daily production traits were lower for the first group of goats for $\mathrm{dMY}(-13 \%)$, dCY $(-10 \%)$, dCY $\mathrm{dCliDS}_{\text {S }}(-7 \%)$, and $\mathrm{dCY}_{\mathrm{WATER}}(-13 \%)$ when compared with the other groups.

The variation during lactation (reported in Table 4) was significant for all the milk components except fat. Nutrient recovery was slightly affected by DIM (exclud-

Table 2. Variances of the random effects for milk composition, cheesemaking traits, and daily productions of goat milk samples

\begin{tabular}{|c|c|c|c|c|}
\hline \multirow[b]{2}{*}{ Trait } & \multicolumn{3}{|c|}{ Random effect, $\%$} & \multirow[b]{2}{*}{$\mathrm{RMSE}^{1}$} \\
\hline & Farm & Animal & Glass tube & \\
\hline \multicolumn{5}{|l|}{ Milk composition } \\
\hline Fat, $\%$ & 54.0 & - & - & 0.85 \\
\hline Protein, $\%$ & 33.1 & - & - & 0.34 \\
\hline Casein, \% & 38.3 & - & - & 0.29 \\
\hline Casein index ${ }^{2}$ & 47.5 & - & - & 0.02 \\
\hline Lactose, $\%$ & 33.9 & - & - & 0.20 \\
\hline TS, \% & 51.6 & - & - & 1.03 \\
\hline $\mathrm{pH}$ & 52.8 & - & - & 0.07 \\
\hline $\mathrm{SCS}^{3}$ & 28.8 & - & - & 1.63 \\
\hline $\mathrm{LBC}^{4}$ & 63.5 & - & - & 0.51 \\
\hline \multicolumn{5}{|c|}{ Nutrient recovery (\%REC), \% } \\
\hline$\% \mathrm{REC}_{\mathrm{FAT}}$ & 17.1 & 82.7 & 0.01 & 0.21 \\
\hline$\%$ REC $_{\text {PROTEIN }}$ & 18.5 & 80.8 & 0.04 & 0.20 \\
\hline$\% \mathrm{REC}_{\text {SOLIDS }}$ & 34.7 & 64.1 & 0.07 & 0.49 \\
\hline$\% \mathrm{REC}_{\text {ENERGY }}$ & 27.4 & 71.9 & 0.03 & 0.37 \\
\hline \multicolumn{5}{|c|}{ Cheese yield (\%CY), \% } \\
\hline$\% \mathrm{CY}_{\mathrm{CURD}}$ & 31.3 & 60.8 & 0.00 & 0.73 \\
\hline$\% \mathrm{CY}_{\text {SOLIDS }}$ & 44.7 & 55.1 & 0.01 & 0.07 \\
\hline$\% \mathrm{CY}_{\text {WATER }}$ & 29.0 & 49.5 & 0.00 & 0.69 \\
\hline \multicolumn{5}{|c|}{ Theoretical (Th) CY, \% } \\
\hline$T h-\% \mathrm{CY}_{\mathrm{CURD}}$ & 46.1 & 53.9 & - & 0.00 \\
\hline$T h-\% \mathrm{CY}_{\text {SOLIDS }}$ & 38.7 & 61.3 & - & 0.00 \\
\hline \multicolumn{5}{|c|}{ Cheesemaking efficiency (Eff), \% } \\
\hline Eff- $\%$ CY & 19.4 & 69.9 & 0.00 & 5.10 \\
\hline Eff- $\% \mathrm{CY}_{\text {SOLIDS }}$ & 19.6 & 77.5 & 0.13 & 0.96 \\
\hline \multicolumn{5}{|c|}{ Daily (d) production traits, $\mathrm{kg} / \mathrm{d}$} \\
\hline dMilk yield & 53.4 & 47.0 & - & 0.58 \\
\hline $\mathrm{dCY} \mathrm{CURD}_{\mathrm{CUR}}$ & 50.1 & 48.5 & 0.00 & 0.01 \\
\hline $\mathrm{dCY}_{\text {SOLIDS }}$ & 48.8 & 51.2 & 0.00 & 0.00 \\
\hline $\mathrm{dCY}_{\text {WATER }}$ & 52.2 & 43.6 & 0.02 & 0.01 \\
\hline
\end{tabular}


ing $\% \mathrm{REC}_{\text {ENERGY }}$ ), exhibiting a quadratic trend along lactation. It can be seen from Figure 1 that during lactation $\% \mathrm{REC}_{\mathrm{FAT}}$ was characterized by a pattern opposite \% REC $_{\text {PROTEIN }}$; less marked was the pattern shown by $\% \mathrm{REC}_{\text {SOLIDS. }}$. We found greater values of actual $\% \mathrm{CY}_{\mathrm{CURD}}$ and $\% \mathrm{CY}_{\text {SOLIDS }}$ at the end of lactation. Daily production traits were linearly affected by DIM, showing a decrease during lactation.

\section{Effect of Goat Breed}

Least squares means and related orthogonal contrasts ( $F$-values and significance) for milk quality and cheesemaking traits of the 6 breeds are reported in Table 5 . These least squares means are corrected for all the other factors of variation included in base model [1].

Comparing least squares means of the Alpine type breeds (Sa and CA) with the Mediterranean (MG, Ma,
Sr, and SP), 6 out of 8 milk quality traits, and 9 out of 15 cheesemaking traits were better for the latter group of breeds. Our findings confirmed the lower milk productivity potential of Mediterranean goats in terms of dMY $(-70 \%), \mathrm{dCY}_{\mathrm{CURD}}(-54 \%), \mathrm{dCY}_{\text {SOLIDS }}(-60 \%)$, and $\mathrm{dCY}_{\text {WATER }}(-62 \%)$ when compared with the $2 \mathrm{Al}-$ pine breeds, only partly compensated by greater actual $\% \mathrm{CY}_{\text {CURD }}(19 \%), \% \mathrm{CY}_{\text {SOLIDS }}(21 \%)$, and $\% \mathrm{CY}_{\text {WATER }}$ $(15 \%)$. This was due not only to higher milk fat, protein, and casein contents, but also to the greater \%REC showed by Mediterranean breeds. Theoretical cheese yields (both $T h-\% \mathrm{CY}_{\mathrm{CURD}}$ and $T h-\% \mathrm{CY}_{\text {SOLIDS }}$ ), based on milk composition, showed higher values for Mediterranean over the Alpine breeds. However, it is interesting to focus on the differences between the actual and theoretical cheese yields, as their ratio provides an estimate of the global efficiency of cheesemaking process. As shown in Table 5, both cheesemaking efficiencies

Table 3. Effect of parity on milk composition, daily productions, and cheesemaking traits of individual goats

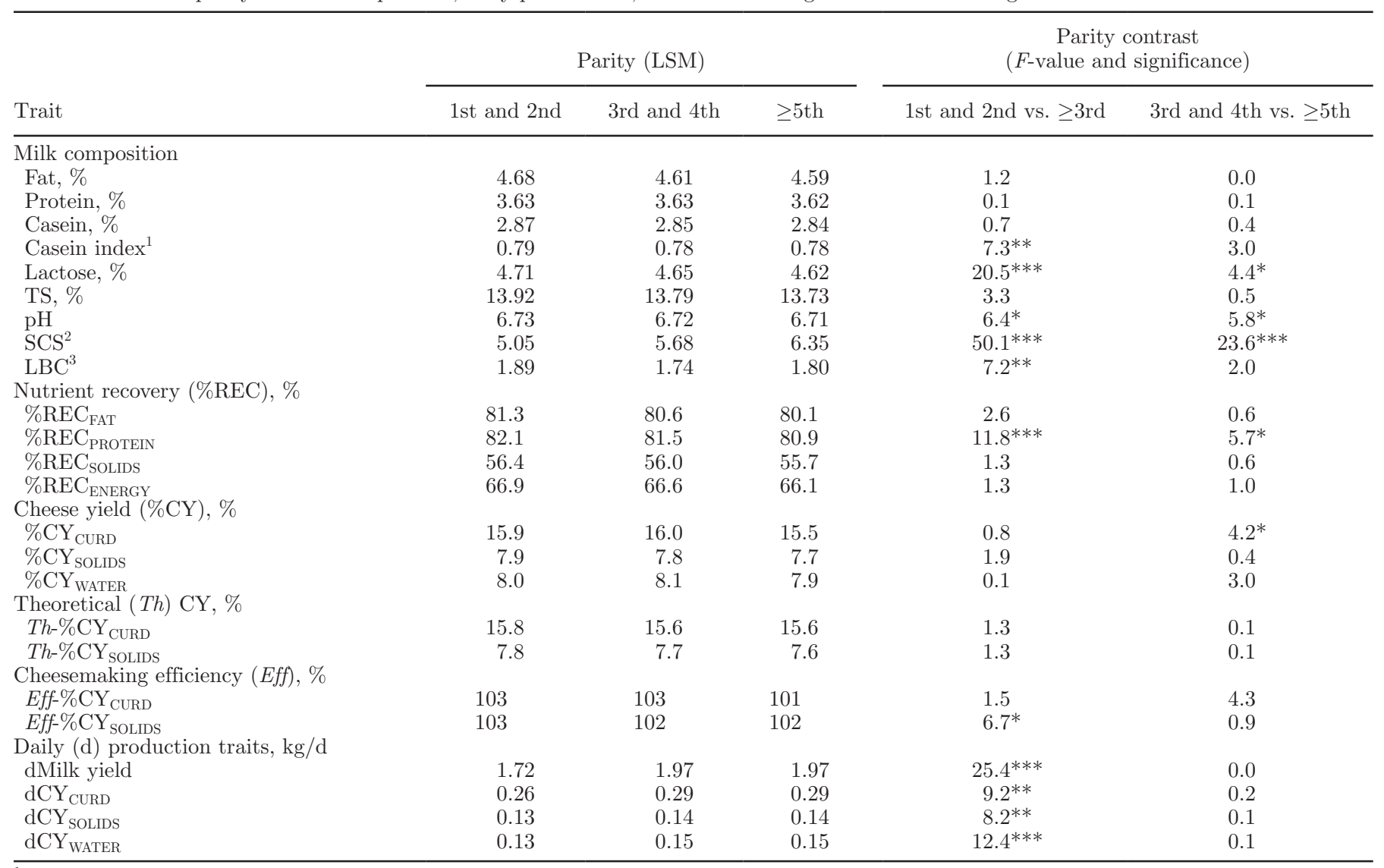

${ }^{1}$ Casein index: casein to protein ratio.

${ }^{2} \mathrm{SCS}=\log _{2}\left(\mathrm{SCC} \times 10^{-5}\right)+3$.

${ }^{3} \mathrm{LBC}=\log$ arithmic total bacterial count $=\log _{10}$ (total bacterial count $\left./ 1,000\right)$.

${ }^{*} P<0.05 ;{ }^{* *} P<0.01 ;{ }^{* * *} P<0.001$. 
Table 4. Effect of DIM and orthogonal contrast for linear, quadratic and cubic trend on milk composition, daily productions, and cheesemaking traits of individual goats

\begin{tabular}{|c|c|c|c|c|c|c|c|}
\hline \multirow[b]{2}{*}{ Trait } & \multicolumn{4}{|c|}{ DIM (LSM) } & \multicolumn{3}{|c|}{$\begin{array}{c}\text { DIM contrasts } \\
(F \text {-value and significance })\end{array}$} \\
\hline & $<80$ & $80-120$ & $121-160$ & $>160$ & Linear & Quadratic & Cubic \\
\hline \multicolumn{8}{|l|}{ Milk composition } \\
\hline Fat, \% & 4.68 & 4.68 & 4.50 & 4.64 & 0.6 & 0.8 & 2.7 \\
\hline Protein, \% & 3.58 & 3.49 & 3.64 & 3.78 & $24.8^{* * *}$ & $15.7^{* * *}$ & $4.0^{*}$ \\
\hline Casein, \% & 2.82 & 2.74 & 2.86 & 2.99 & $20.5^{* * *}$ & $16.4^{* * *}$ & 3.1 \\
\hline TS, $\%$ & 13.92 & 13.73 & 13.67 & 13.93 & 0.0 & $6.9^{* *}$ & 0.3 \\
\hline $\mathrm{pH}$ & 6.75 & 6.72 & 6.71 & 6.70 & $26.7^{* * *}$ & 1.0 & 0.2 \\
\hline $\mathrm{SCS}^{2}$ & 5.20 & 5.63 & 5.52 & 6.42 & $24.5^{* * *}$ & 3.1 & $7.1^{* *}$ \\
\hline $\mathrm{LBC}^{3}$ & 1.76 & 1.76 & 1.80 & 1.92 & $4.8^{*}$ & 2.2 & 0.1 \\
\hline \multicolumn{8}{|c|}{ Nutrient recovery (\%REC), \% } \\
\hline$\% \mathrm{REC}_{\mathrm{FAT}}$ & 81.5 & 80.4 & 79.8 & 81.0 & 0.4 & $3.9^{*}$ & 0.2 \\
\hline$\%$ REC $_{\text {PROTEIN }}$ & 81.1 & 81.9 & 81.7 & 81.4 & 0.4 & $5.2^{*}$ & 0.5 \\
\hline \multicolumn{8}{|c|}{ Cheese yield (\%CY), \% } \\
\hline$\% \mathrm{CY}_{\text {WATER }}$ & 8.1 & 7.9 & 8.0 & 8.1 & 0.0 & 1.3 & 0.1 \\
\hline \multicolumn{8}{|c|}{ Theoretical ( Th) CY, \% } \\
\hline Th- $\% \mathrm{CY}_{\mathrm{CURD}}$ & 15.7 & 15.6 & 15.4 & 16.0 & 0.7 & 4.3 & 0.1 \\
\hline Th-\% CY & 7.7 & 7.6 & 7.6 & 7.8 & 0.7 & 4.3 & 0.6 \\
\hline \multicolumn{8}{|c|}{ Cheesemaking efficiency (Eff). \% } \\
\hline Eff-\% CY & 104 & 103 & 102 & 101 & 2.9 & 0.3 & 0.0 \\
\hline Eff- $\% \mathrm{CY}_{\text {SOLIDS }}$ & 102 & 102 & 102 & 103 & 1.2 & 1.1 & 1.0 \\
\hline \multicolumn{8}{|c|}{ Daily (d) production traits, $\mathrm{kg} / \mathrm{d}$} \\
\hline dMilk yield & 2.02 & 1.90 & 1.85 & 1.75 & $10.5^{* *}$ & 0.0 & 0.3 \\
\hline $\mathrm{dCY}_{\mathrm{CURD}}$ & 0.30 & 0.28 & 0.27 & 0.27 & $3.9^{*}$ & 0.5 & 0.0 \\
\hline $\mathrm{dCY}_{\text {SOLIDS }}$ & 0.15 & 0.14 & 0.13 & 0.13 & 2.8 & 0.8 & 0.1 \\
\hline $\mathrm{dCY}_{\text {WATER }}$ & 0.16 & 0.15 & 0.14 & 0.14 & $4.8^{*}$ & 0.7 & 0.0 \\
\hline
\end{tabular}

${ }^{1}$ Casein index: casein to protein ratio.

${ }^{2} \mathrm{SCS}=\log _{2}\left(\mathrm{SCC} \times 10^{-5}\right)+3$.

${ }^{3} \mathrm{LBC}=\operatorname{logarithmic}$ total bacterial count $=\log _{10}$ (total bacterial count $\left./ 1,000\right)$.

${ }^{*} P<0.05 ;{ }^{* *} P<0.01 ;{ }^{* * *} P<0.001$.

of Mediterranean goats did not differ from the Alpine goats, confirming that the differences in actual \%CY traits were mainly due to fat and casein content of milk.

Compared with Sa, CA presented no differences in terms of milk components, daily production, and actual cheese yields traits, but had greater recovery of nutrients in the curd (1.4\% for protein, $5.0 \%$ for solids, and $5.1 \%$ for energy). Theoretical $\% \mathrm{CY}$ were also not different between the 2 breeds of Alpine type, but Eff$\% \mathrm{CY}_{\text {SOLIDS }}$ was higher in CA goats.

Within Mediterranean breeds, Italian goats had a lower daily milk yield ( $-66 \% \mathrm{dMY})$ and also cheese production when compared with MG $(-60,-66$, and $-55 \%$ for $\mathrm{dCY}_{\text {CURD }}, \mathrm{dCY}_{\text {SOLIDS }}$, and $\mathrm{dCY}_{\text {WATER }}$, respectively), partly compensated by greater values of all actual \% CY (10\%) and \% REC traits (4.4\% for fat, $1.4 \%$ for protein, $5.0 \%$ for solids, and $4.5 \%$ for energy).

The differences found among the 3 Italian breeds were even larger. The Maltese breed produced more milk and cheese per day than the 2 local Sardinian breeds, but had, on average, lower actual \%CY due to lower milk fat and protein contents and lower $\% \mathrm{REC}_{\mathrm{FAT}}, \% \mathrm{REC}_{\mathrm{SOLIDS}}$, and $\% \mathrm{REC}_{\text {ENERGY}}$. The theoretical $\% T h$-CY $\mathrm{C}_{\text {SOLIDS }}$, as expected, confirmed that the 2 local Sardinian breeds were superior to Maltese goats, whereas $E f f-\% \mathrm{CY}_{\text {SOLIDS }}$ were, on average, lower for the 2 local breeds due to the lower predicted $T h-\% \mathrm{CY}_{\mathrm{CURD}}$. The only difference found between the 2 local breeds from Sardinia was for the Eff-\% $\mathrm{CY}_{\mathrm{CURD}}$, slightly lower in the SP breed.

\section{DISCUSSION}

\section{Cheesemaking Ability of Goat Milk}

As far we are aware, no previous studies in the literature have processed a high number of goat milk samples to mimic the complex process of cheesemaking using a small-scale laboratory method that allows the esti- 
mation of 4 recoveries of nutrients (\%REC), 3 actual (\%CY), 2 theoretical ( $T h-\% \mathrm{CY}), 2$ efficiencies of cheesemaking $(E f f-\% \mathrm{CY})$, and 3 daily cheese productions $(\mathrm{dCY})$ traits. The protocol used in our study allowed us to process 560 individual milk samples with 2 replicates. With respect to other laboratory procedures based on very limited quantity of milk and separating the curd through centrifugation, the 9-mL milk cheesemaking assessment allows for obtaining \% CY and \% REC traits from bovine milk very similar to those found in practice, especially in relation to efficiency of curd draining and representativeness of milk fat recovery in the curd (Cipolat-Gotet et al., 2016a).

In the present study, actual $\% \mathrm{CY}_{\mathrm{CURD}}$ was the same as the average value obtained by Stocco et al. (2018) from milk of 6 breeds of cows, slightly higher compared with Cipolat-Gotet et al. (2013) from Brown Swiss cows, and lower compared with results from Sarda sheep (Cipolat-Gotet et al., 2016b). Goat \% REC $_{\text {FAT }}$ was lower when compared with bovine and ovine, and was similar to that reported by Fekadu et al. (2005) in their study on goat milk (Alpine breed). These differences among species could be explained by the different fat globules-casein matrix interactions, besides fat globules dimension, which are smaller for goat milk (Attaie and Richter, 2000). The $\%$ REC $_{\text {PROTEIN }}$ in goats was superior to cow and sheep and also compared with goat milk protein recovery found by Chen et al. (2010), and was closer to values found for a 500-mL cheesemaking procedure using individual buffalo milk samples (80.4\%) by Cipolat-Gotet et al. (2015). Goat \%REC SOLIDS $_{\text {were }}$ higher compared with cows and lower compared with sheep and buffaloes. Because of these differences in the recovery of nutrients in the curd, \% REC $_{\text {ENERGY }}$ was slightly lower in goats compared with the studies on bovines, and especially on buffalo and sheep milk.

\section{Effect of Farm and Animal on Cheesemaking Traits}

It is recognized that $\% \mathrm{CY}_{\mathrm{CURD}}$ depends primarily on the TS content of the milk, its recovery in curd, and the retention of water in cheese (Cecchinato and Bittante, 2016). The amount of solids retained in the curd depends largely on the fat and casein contents of the milk, as lactose and mineral fraction are retained at very low levels. However, water retention in cheese is mainly influenced by several factors, including processing conditions (i.e., mode and time of the cutting phase, the draining and pressing of wheels and the extent of ripening; Remeuf et al., 1991; Janhøj and Qvist, 2010). For these reasons, among \% CY traits, \% $\mathrm{CY}_{\text {WATER }}$ was less affected by animal effect (Table 2). To exclude the

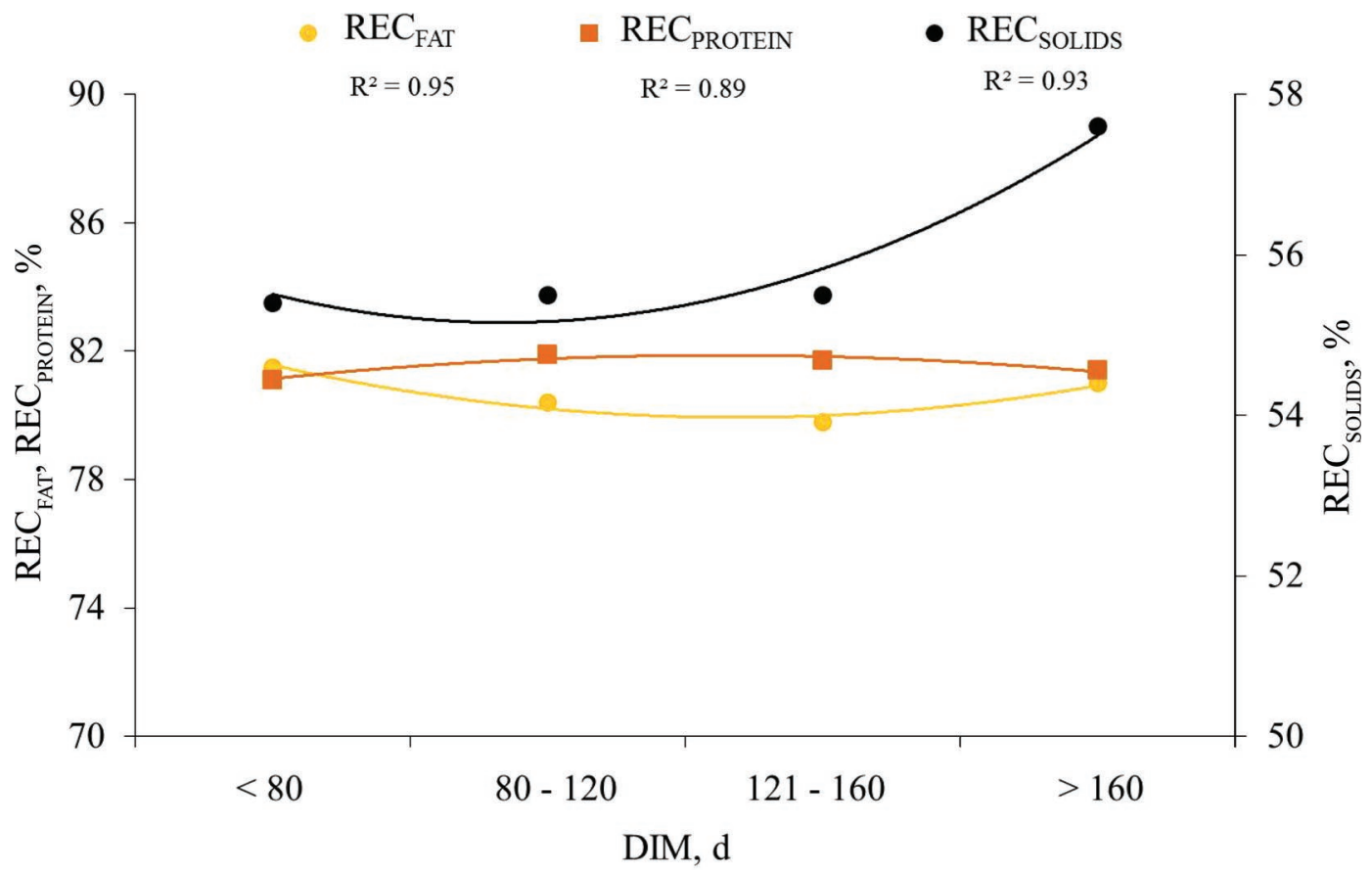

Figure 1. Effect of DIM on milk fat, protein, and solids recovery (REC) in the curd. Results of the polynomial contrasts have been reported: the quadratic response curve of the data according to lactation, and the coefficient of determination $\left(\mathrm{R}^{2}\right)$ of the regression. Color version available online. 
BREED OF GOATS, CHEESE YIELD, AND EFFICIENCY

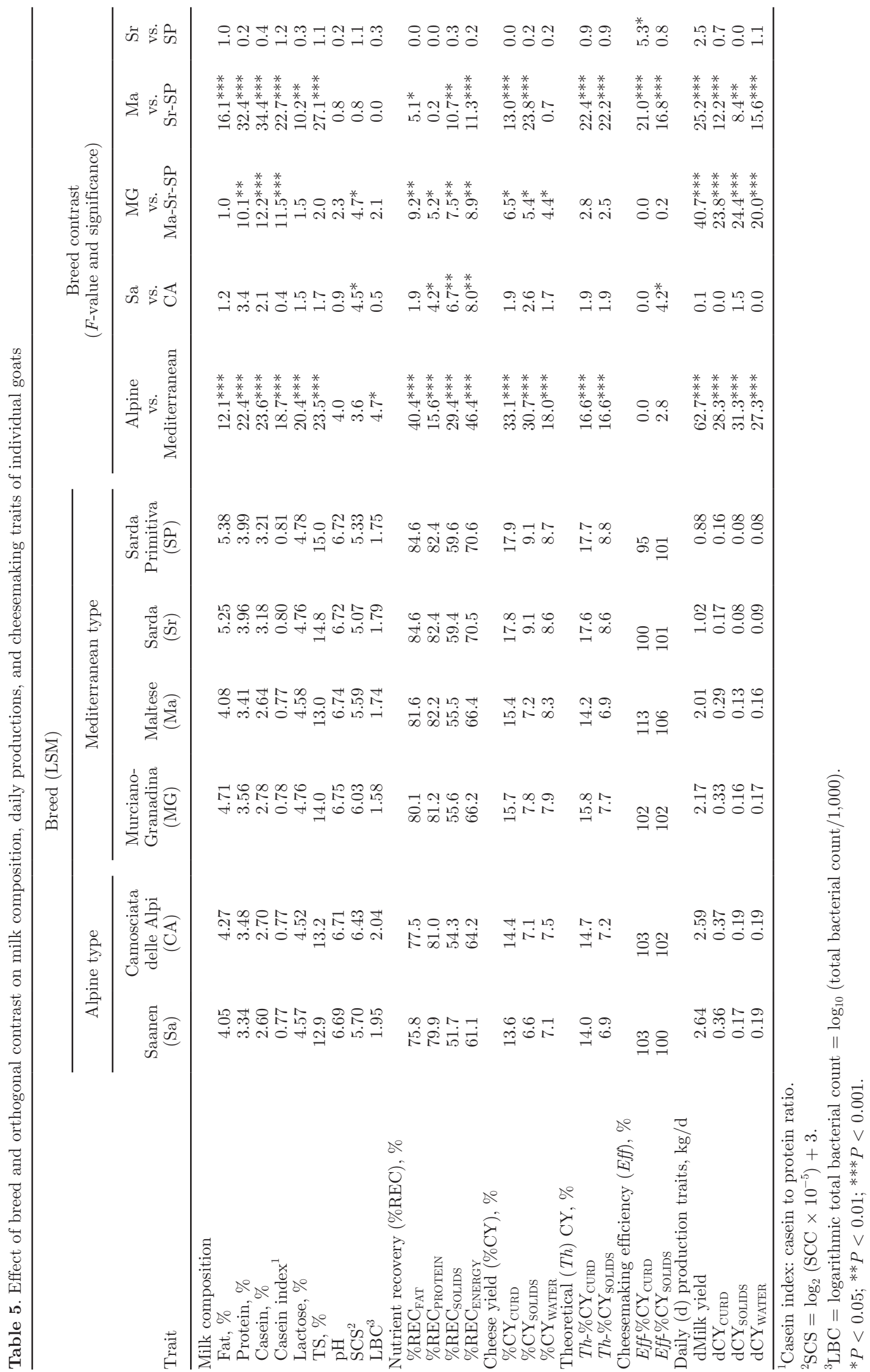


effect of variations in the water content of the cheese, some researchers calculated the $\% \mathrm{CY}_{\text {SOLIDS }}$ as the ratio between the DM content of the cheese and the weight of the processed milk (Fagan et al., 2007). In the case of model cheeses produced using very small amounts of milk (10 mL), Melilli et al. (2002) directly estimated $\% \mathrm{CY}_{\text {SOLIDS. }}$ However, those authors used that procedure to predict the results obtained with the formula of Van Slyke and Publow (1910), obtaining an average $\% \mathrm{CY}_{\text {SOLIDS }}$ of $6.59 \%$, whereas we found $7.7 \%$ for the actual $\% \mathrm{CY}_{\text {SOLIDS }}$ and $7.4 \%$ for $T h-\% \mathrm{CY}_{\text {SOLIDS }}$ with the formula of Van Slyke and Price (1949). The differences can be largely explained by differences in milk composition and in cheesemaking protocols; specifically, the use of centrifugation instead of curd cooking and draining is known to reduce the efficiency of whey separation, to overestimate all \%CY and \%REC traits, and to worsen the repeatability of the measures (Cipolat-Gotet et al., 2016a). In our study TS represented $49 \%$ of the fresh curd, so water contributed slightly more than TS to both percentage and daily cheese yields (8.0 vs. $7.7 \%$ and 0.15 vs. $0.14 \mathrm{~kg} / \mathrm{d}$, respectively).

The $\% \mathrm{REC}_{\mathrm{FAT}}$ and $\% \mathrm{REC}_{\mathrm{PROTEIN}}$ quantify the complex phenomena through which fat and proteins are transferred from milk to cheese (Emmons et al., 2003), so the loss of fat and proteins in whey reduces cheese yield (Hallén et al., 2010). In the past, almost all the predictive formulae for estimating cheese yield have been based on knowledge of the protein and fat contents of milk, or the sum of the fat and protein, and TS contents (Zeng et al., 2007; Emmons and Modler, 2010). All those formulae assume that the recovery of milk protein (casein) and fat in the curd is constant. However, it has been proved that those traits are not only highly variable (Stocco et al., 2018), but have larger heritability than milk protein and fat contents (Bittante et al., 2013). Actually, the incidence of the animal effect was very high for these traits (82.7 and $80.8 \%$, respectively, for $\% \mathrm{REC}_{\mathrm{FAT}}$ and $\left.\% \mathrm{REC}_{\text {PROTEIN }}\right)$, and was the highest among all cheesemaking traits (Table 2). This suggested that the improvement of \%REC and \%CY traits should be based principally on individual animal factors (i.e., breed, genetics, parity, stage of lactation), whereas farming system (facilities, management, nutrition) played a much more important role in the level of production and hygienic conditions $(\mathrm{LBC}=63.5 \%$; Table 2$)$. Similar results were found by Cipolat-Gotet et al. (2013) in bovine; in particular, they reported values of variability due to herd date from 21 to $31 \%$ for \%REC traits, from 24 to $42 \%$ for actual \%CY traits, and from 51 to $53 \%$ for dCY traits. Stocco et al. (2018) found lower herd date incidence compared with the present study, from 11 to $17 \%$ for
\%REC traits, from 19 to $29 \%$ for actual \%CY traits, from 42 to $46 \%$ for dCY traits, $15 \%$ for both $T h-\% \mathrm{CY}$, and 10 and $17 \%$, respectively, for Eff- $\% \mathrm{CY}_{\mathrm{CURD}}$ and Eff$\% \mathrm{CY}_{\text {SOLIDS. }}$ However, it is worth noting that herd date in Stocco et al. (2018) was included in the statistical model as a random effect within class of herd productivity. As in the case of Sarda sheep (Cipolat-Gotet et al., 2016b), the effect of flock was higher compared with our study for \%REC (from 13 to 56\%) and actual \%CY traits (from 43 to $49 \%$ ) and lower for dCY productions (from 18 to $42 \%$ ).

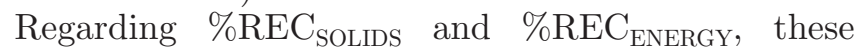
have never been studied before in goat milk. Their variability was mostly under the animal control (64.1 and $71.9 \%$, respectively; Table 2), even more than single milk components. It is important to remember that, as reported in a previous study on genetic parameters of different measures of cheese yield and milk nutrient recovery in bovine milk, from the genetic point of view $\% \mathrm{REC}_{\text {PROTEIN }}$ is not directly correlated with the cheese yield, but with $\% \mathrm{REC}_{\text {SOLIDS }}$ and $\% \mathrm{REC}_{\text {ENERGY }}$, which are strongly related to the \% CY traits (Bittante et al., 2013).

\section{Individual Animal Factors on Cheesemaking Traits}

No previous study examined the effect of parity on cheese yield and cheesemaking traits of goat milk. It is interesting to note that, although daily production traits decreased across parities, \%REC significantly higher for goats belonging to the first group. However, the other traits were not statistically different across classes of parity. This meant that, although the dMY increased with the age of the goat, \%REC and \%CY did not augment throughout parities. Among milk quality traits, only lactose, SCS, and LBC changed across parities. Similar results for parity on cheesemaking traits were found for buffalo (CipolatGotet et al., 2015) and bovine milk (Cipolat-Gotet et al., 2013; Stocco et al., 2018), whereas in sheep parity affect only $\% \mathrm{REC}_{\text {SOLIDS }}$ and daily milk and cheese productions (Cipolat-Gotet et al., 2016b).

With regard to DIM, marked changes occur in the composition of bovine milk throughout the year, especially when milk is produced mainly from springcalving farms fed predominantly on pasture (Fox et al., 2000 ), because the progression of lactation is parallel to the seasonal change in quantity and quality of herbage available. For goat species, Fekadu et al. (2005) reported that the significant variation of the chemical composition of milk over 6 mo of lactation causes the variation of $\% \mathrm{CY}_{\mathrm{CURD}}, \% \mathrm{REC}_{\mathrm{FAT}}$, and $\% \mathrm{REC}_{\mathrm{PROTEIN}}$. In particular, for hard cheese production, the measured 
$\% \mathrm{CY}$ is higher at early and late stages of lactation compared with mid-lactation, in agreement with the quadratic trend found in the present study. The findings of Fekadu et al. (2005) correspond to the changes in fat, protein, and TS content of milk. On the contrary, for semihard cheese production, only milk from the last month of lactation results in a higher \%CY than milk from other stages. Fekadu et al. (2005) found that both protein and fat recovery in hard cheese varies during lactation, but without a particular discernible pattern. In fact, it appeared that \% CY does not correspond to the changes of \%REC. In our study, most of the milk nutrient components that were entrapped in the curd had a quadratic trend during lactation. This could explain the patterns of actual \%CY and \%REC (Figure 1) traits, confirming data found by Cipolat-Gotet et al. (2013). The seasonal changes in milk composition, which are most pronounced at the extremes of lactation, result in variations not only in recovery of fat and protein, cheese yield, and milk quality, but also in milk coagulation properties and in curd-firming over time parameters (Pazzola et al., 2018; Vacca et al., 2018). In those studies, the technological properties of individual goat milk samples from late lactation were superior to those of early-or mid-lactation milk, and justify the higher value of actual $\% \mathrm{CY}_{\mathrm{CURD}}$ at the end of the period we found. This was not because of the higher water retention in the curd (which indeed did not change throughout the lactation), but because of the increment in $\% \mathrm{REC}_{\text {SOLIDS }}\left(\% \mathrm{CY}_{\text {SOLIDS }}\right.$ increased as well). On the contrary, in sheep \% $\mathrm{CY}$ traits, \% $\mathrm{REC}_{\mathrm{SOLIDS}}$, and \%RE$\mathrm{C}_{\text {ENERGY }}$ increase linearly during the lactation period (Cipolat-Gotet et al., 2016b).

\section{Effect of Breed of Goat on Cheesemaking Traits}

As mentioned, no previous studies have processed milk from many animals of 6 breeds of goat to obtain a complete balance of their cheesemaking efficiency. However, information on \%CY comparison of some breeds is available.

Using an experimental model cheese procedure, Damiàn et al. (2008) compared the individual laboratory cheese yield (ILCY), casein fractions, and major milk components of 11 Saanen and 11 Anglo-Nubian goats raised under the same semi-intensive system. The 2 breeds were significantly different for all the traits considered, lactose excluded. With regard to ILCY, it was $48 \%$ higher in the Anglo-Nubian breed compared with Saanen goats. Damiàn et al. (2008) also found that ILCY was strongly related to casein fractions, in particular $\alpha_{\mathrm{S}_{1}}$ CN. Soryal et al. (2005) observed large differences between 12 Nubian and 12 Alpine goats in
$\% \mathrm{CY}_{\mathrm{CURD}}(2.71$ vs. $1.69 \mathrm{~kg} / 10 \mathrm{~kg}$ of milk, respectively). Those authors did not perform any cutting and pressing, and the average values were very high, probably because of the large amounts of moisture retained in the curd.

Other information are available from studies using bulk milk produced by experimental or commercial farms and processed in small-scale dairy plants. Kouniba et al. (2007) studied the effect of goat breed on milk composition and $\% \mathrm{CY}_{\mathrm{CURD}}$ from a local breed from the north of Morocco compared to Alpine goats. The milk of the Moroccan breed was characterized by significantly higher DM, fat, and total nitrogen than Alpine breed - as was the case in the comparison of Alpine and Mediterranean breeds in our study - as well as greater actual $\% \mathrm{CY}_{\mathrm{CURD}}(28.3$ vs. $17.3 \%$,). Herrera et al. (2010) studied \% $\mathrm{CY}_{\mathrm{CURD}}$ of bulk milk samples from Anglo-Nubian, Saanen, Alpine, and Toggenburg goats after draining and pressing, as in the present study. Those authors reported greater $\% \mathrm{CY}_{\mathrm{CURD}}$ for AngloNubian breed compared with the others (17.4 vs. 12.6, 12.7, and $12.9 \%$ for Anglo-Nubian, Saanen, Alpine, and Toggenburg, respectively).

From previous studies, breeds of Alpine origin always show poor results compared with the other breeds when assessed in terms of \%CY ${ }_{\text {CURD }}$. We confirmed (Table 5) that Alpine breeds ( $\mathrm{Sa}$ and $\mathrm{CA}$ ) were characterized by lower TS and poorer overall cheesemaking ability when compared with Mediterranean dairy breeds. The latter goats are known for their lower daily milk yield, but also for higher milk fat and protein contents and, consequently, for greater actual $\% \mathrm{CY}_{\mathrm{CURD}}$ (Figure 2) and \%REC traits (Figure 3). As the $T h-\% \mathrm{CY}_{\mathrm{CURD}}$ is based on the fat and casein contents of milk, assuming constant recovery rate for both components, the difference between the theoretical and actual yields depends mainly on their nutrient recovery. However, the better \%REC traits in Mediterranean breeds could be explained, in part, by milk coagulation, curd-firming, and syneresis properties. Previous studies on the same goats found better traditional milk coagulation properties in Mediterranean dairy goats than Alpine ones (Vacca et al., 2018), even greater when the entire pattern of the curd-firming process was modeled (Pazzola et al., 2018). Rapid milk coagulation and, especially, efficient curd-firming and syneresis rates have been found to result in favorable genetic and phenotypic correlations with regard to \% CY and \%REC traits in bovine milk, especially for those parameters recorded at maximum curd firmness or later (Cecchinato and Bittante, 2016).

On a smaller scale, similar interpretations could be applied when comparing the 2 Alpine specialized dairy goats breeds (Sa vs. CA). The superiority of the CA 


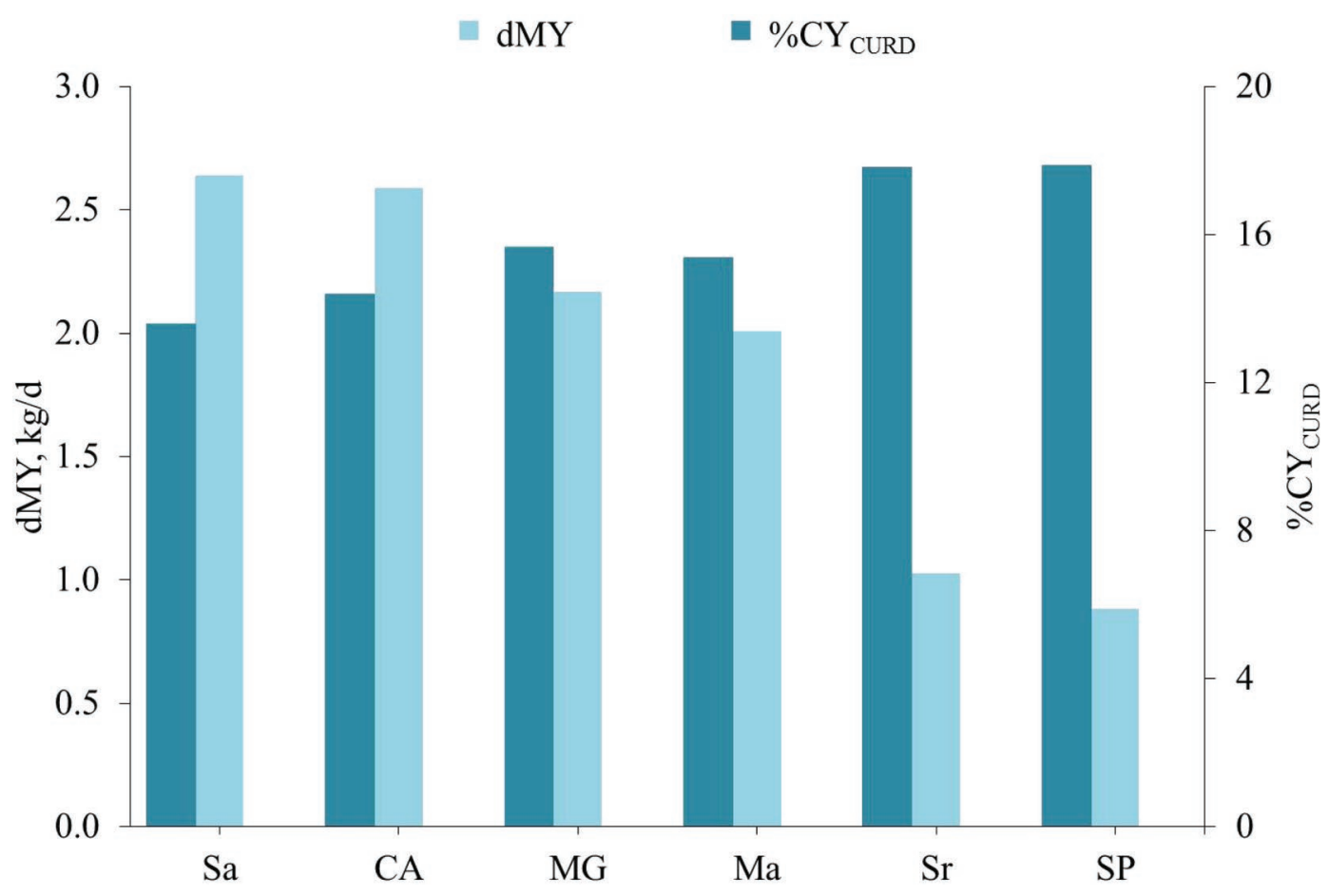

Figure 2. Effect of breed on daily milk yield $(\mathrm{dMY})$ and percentage actual cheese yield $\left({ }_{\mathrm{C}} \mathrm{CY}_{\mathrm{CURD}}\right)$. Sa $=$ Saanen; CA $=$ Camosciata delle Alpi; MG = Murciano-Granadina; Ma = Maltese; $\mathrm{Sr}=$ Sarda; $\mathrm{SP}=$ Sarda Primitiva. Color version available online.

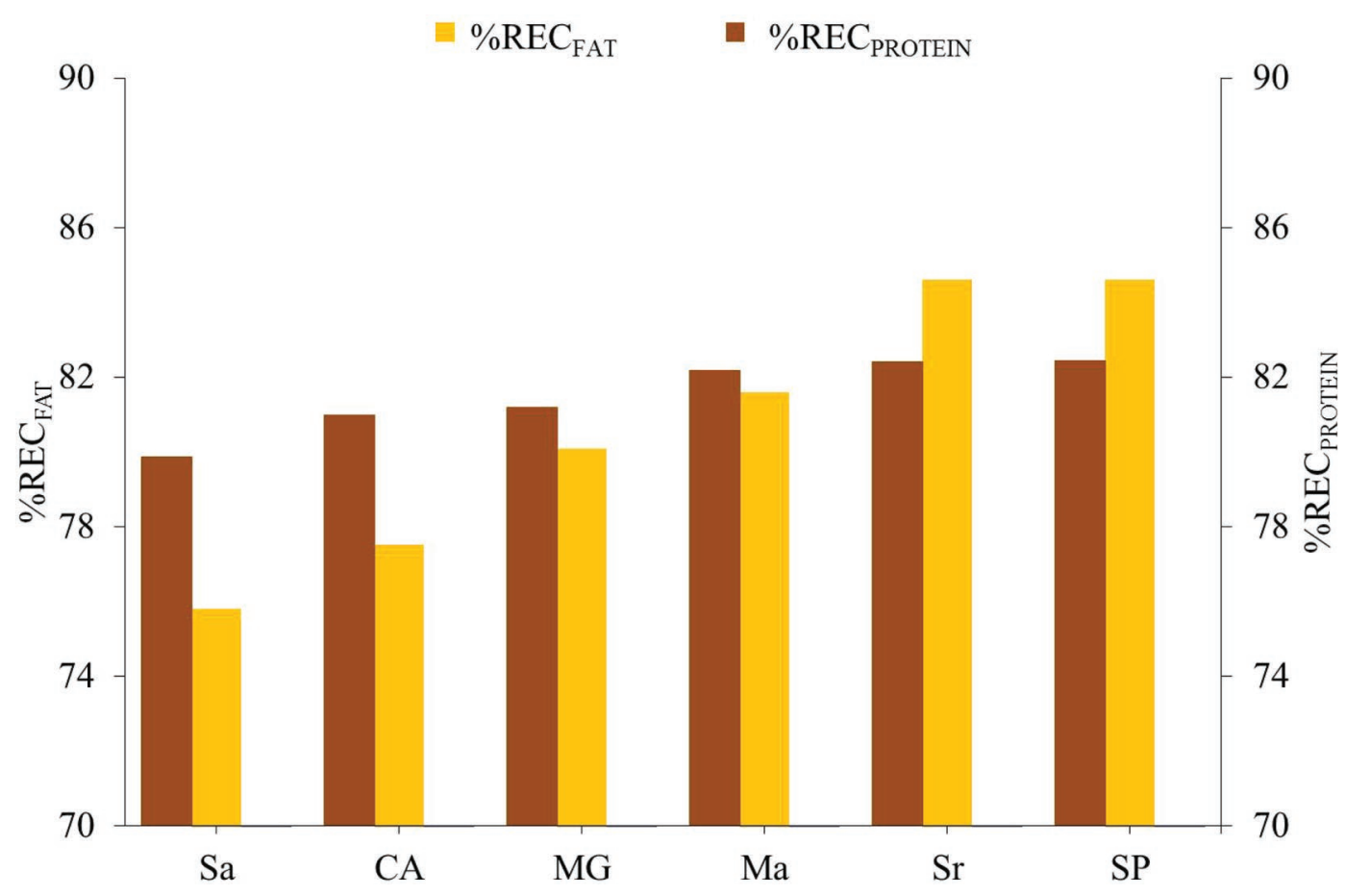

Figure 3. Effect of breed on fat $\left(\% \mathrm{REC}_{\mathrm{FAT}}\right)$ and protein $\left(\% \mathrm{REC}_{\mathrm{PROTEIN}}\right)$ recovery in the curd. Sa $=$ Saanen; CA = Camosciata delle Alpi; $\mathrm{MG}=$ Murciano-Granadina; $\mathrm{Ma}=$ Maltese; $\mathrm{Sr}=$ Sarda; $\mathrm{SP}=$ Sarda Primitiva. Color version available online. 
breed is, in fact, not based on milk composition, but on efficient curd-firming, curd firmness, and syneresis (Pazzola et al., 2018), which led to an overall better cheesemaking process, with higher recovery of fat and protein in the curd (Figure 3), and a slightly higher Eff- $\% \mathrm{CY}_{\text {SOLIDS. }}$.

Within Mediterranean breeds, we were able to confirm that the 3 Italian breeds had good technological aptitude and much greater \% REC and actual \%CY traits, (Pazzola et al., 2018; Vacca et al., 2018), particularly due to the differences found in protein and TS contents (Table 5). The Spanish breed, MG, was intermediate between the 2 breeds of Alpine origin and the 3 Italian breeds in terms of milk composition, technological properties, and daily milk and cheese yields.

The differences were more accentuated within the Italians. The very good quality of the 2 Sardinian breeds, $\mathrm{Sr}$ and SP, particularly in terms of fat, protein, casein, and TS compared with Ma, not only explained the higher $\% \mathrm{REC}_{\mathrm{FAT}}, \% \mathrm{REC}_{\mathrm{SOLIDS}}$, and $\% \mathrm{REC}_{\text {ENERGY }}$, but also the larger values for actual $\% \mathrm{CY}_{\mathrm{CURD}}$ and $\% \mathrm{CY}_{\text {SOLIDS }}$. The technological superiority of milk from Sardinian breeds only partially counterbalanced the higher daily milk yield that characterize Maltese goats. This is one of the reasons that led farmers to cross Maltese bucks with local Sardinian goats for many generations, with a consequent recombination of the original genetic traits of both breeds (Vacca et al., 2016). However, the composition of milk from Maltese goats was much more similar to that of Alpine goats, although gelation, curdfirming, and syneresis patterns have been shown to be better in Maltese compared with Alpine goats (Pazzola et al., 2018). Maltese goats had greater $\% \mathrm{REC}_{\mathrm{FAT}}$ and greater $\% \mathrm{REC}_{\text {PROTEIN }}$, to a smaller degree, compared with the Sa and CA. It is worth noting that, even after correcting for the effect of farm, parity, and DIM, Ma had the highest overall cheesemaking efficiency (both as Eff- $\% \mathrm{CY}_{\mathrm{CURD}}$ and as $\left.E f f-\% \mathrm{CY}_{\text {SOLIDS }}\right)$ of all the 6 breeds examined in the present study.

Although Sa has undergone an intensive crossing, mainly with Maltese, this breed was not different from the ancient strain, SP, except for Eff-\% CY $\mathrm{CUR}_{\mathrm{CUD}}$. It is clearly depicted in Figure 2 and 3 that both Sa and SP had the greatest actual \%CY and \%REC traits. Previous studies that considered local versus foreign breeds found better performance of the former over the latter (Moatsou et al., 2004; Kouniba et al., 2007).

\section{Direct and Indirect Effects of Breed}

As the 6 breeds of the present study differed considerably from each other, to distinguish and quantify the direct effects of breed (independent from yield and composition) on cheesemaking traits from the indirect breed effects (depending on differences in milk yield and composition), we included dMY, fat, protein, TS, casein, lactose, $\mathrm{pH}, \mathrm{SCS}$, and LBC as linear covariates in model [3]. We then calculated the differences in breed variances with and without covariates for each trait. Figure 4 presented very different proportions of direct and indirect effects according to each examined trait.

Milk yield and composition (indirect effect of breed) accounted for a large proportion of the total breed variance for all \%REC traits, but the extent of the direct effect of breed ranged from $41 \%$ for $\%$ REC $_{\text {ENERGY }}$ to $63 \%$ for $\% \mathrm{REC}_{\text {PROTEIN }}$. The direct effect of breed on actual \%CY traits was much lower, as expected, because of the dependence of these traits on milk composition, in particular on available fat and protein. Nevertheless, it represented a substantial proportion of total variability, being $26 \%$ for actual $\% \mathrm{CY}_{\mathrm{CURD}}$ and representing 36 and $39 \%$, respectively, for the constituent traits $\% \mathrm{CY}_{\text {SOLIDS }}$ and $\% \mathrm{CY}_{\text {WATER }}$. As expected, the theoretical cheese yields were totally dependent on the indirect breed effects, as they were calculated only from milk fat and casein contents (and the moisture content of cheese). Given the ratio between the actual and the theoretical \%CY, the 2 cheesemaking efficiencies were about from half to two-thirds dependent on the direct effect of breed (Figure 4).

With regard to dCY traits, the indirect effect of breed was very large, including the covariates with both dMY and milk composition traits in the model. It is worth noting that the direct effect of breed was similar to or greater than those observed for actual \% CY traits (26\% for $\mathrm{dCY}_{\mathrm{CURD}}, 18 \%$ for $\mathrm{dCY}_{\mathrm{WATER}}$, and $39 \%$ for dCY $\left.{ }_{\text {SOLIDS }}\right)$.

As ours is the first study to investigate the direct and indirect effects of breed on cheesemaking traits of goat milk, no direct comparison is possible with other studies on the same species. However, the direct effect of breed was always higher in goat compared with bovine (Stocco et al., 2018), with the exceptions of

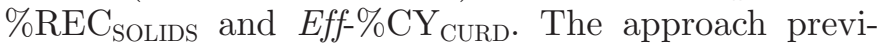
ously taken to examine milk coagulation, curd-firming, and syneresis traits (Pazzola et al., 2018; Vacca et al., 2018) shows that the direct effect of breed represented a great proportion of total breed variance. These traits are important in explaining \% REC and \%CY traits at the phenotypic, genetic, herd, and residual levels, as demonstrated in a previous paper on bovine milk (Cecchinato and Bittante, 2016). It is also important to remember that a variable fraction of the breed effect on coagulation properties is explained by genetic variants of milk proteins (Ambrosoli et al., 1988; Damiàn et al., 2008; Pazzola et al., 2014). Genetic differences between 


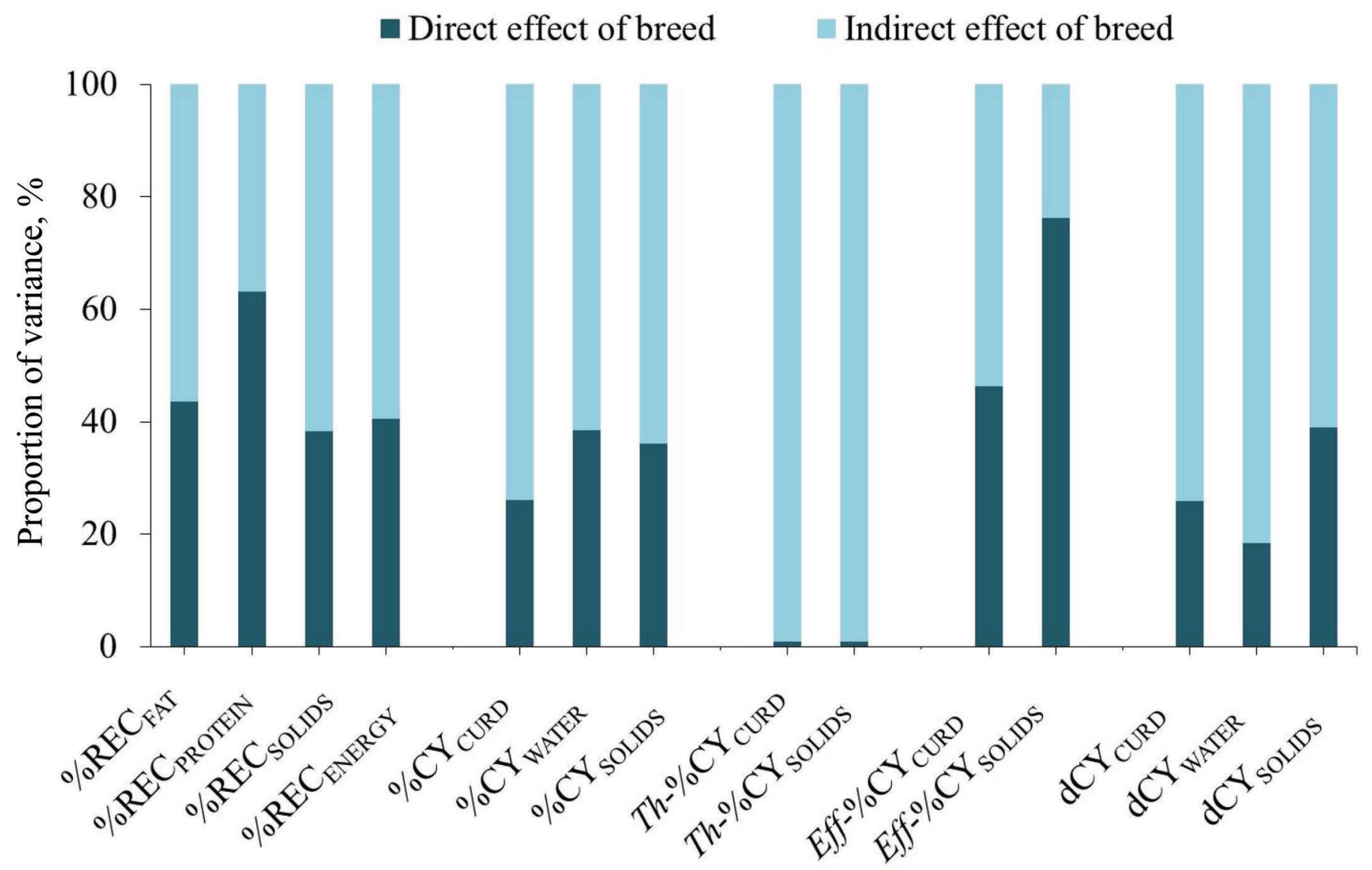

Figure 4. Proportion of total breed variance explained by direct breed effect or by indirect breed effect due to the differences in milk yield and quality traits on nutrient recovery (\%REC), actual cheese yield (\%CY), theoretical (Th) \%CY, \%CY efficicency (Eff), and daily cheese yield $(\mathrm{dCY})$ traits. Color version available online.

Mediterranean and Alpine breeds are mainly present at casein loci, with the prevalence of alleles associated with the highest rates of protein synthesis in breeds belonging to the Mediterranean type (Vacca et al., 2014; Clark and Mora García, 2017). Both milk coagulation traits and milk protein genetic variants could be a part of the factors influencing the direct effect of breed, as defined in the present study.

Among Eff-\%CY traits, in the case of Eff-\% $\mathrm{CY}_{\text {SOLIDS }}$, about one-third of breed variance is due to indirect effects of breed (dMY and composition), even though it represents the ratio between actual $\% \mathrm{CY}_{\text {SOLIDS }}$ and theoretical $T h-\% \mathrm{CY}_{\text {SOLIDS }}$ predicted on the basis of the fat and casein contents of milk. It is evident that this proportion is explained by a different relationship between \%CY and milk fat and casein compared with the Van Slyke and Price (1949) formula (a greater effect of casein and slightly lower effect of fat; data not shown) and by other factors included here as covariates. In particular, the constituents that could be considered in- dicators of the mammary gland health status (lactose, $\mathrm{pH}, \mathrm{SCS}$, and LBC), which need further investigations for goat species.

\section{CONCLUSIONS}

In conclusion, our study confirmed that cheesemaking using goat milk is a complex phenomenon, driven by several factors. The quality of the milk processed, mainly fat and casein, the recovery of these nutrients in the curd, the retention of water in cheese, and overall cheesemaking efficiency all contributed to the percentage cheese yield. Animal factors were responsible for the greatest part of the variability in all traits and, among these factors, breed has proven to be the most important. The 2 breeds of Alpine type, Saanen and Camosciata delle Alpi, seemed to be the most productive but to have the least cheesemaking efficiency, whereas the most efficient out of the dairy breeds appeared to be the Sarda and Sarda Primitiva, as well as 
the Maltese breed, in part. In particular, the 2 local Sardinian breeds, despite their small daily milk production, showed the highest fat and protein content, cheese yields, and recovery rates of their milk. This study also highlighted the differences among these breeds were the result not only of the production potential and nutrient concentrations, but also of the differences in nutrient recovery ability and overall cheesemaking efficiency. Thus, further studies are needed to deepen the relationships among milk components, coagulation process, and cheesemaking traits and clarify the role of each of aspect. New insights provided by this study about the differences among breeds could also give new possibilities and direction in breeding programs.

\section{ACKNOWLEDGMENTS}

Research funded by the Regional Government of Sardinia, Italy (Legge Regionale $7 / 2007$; CUP J72I15000030007). The authors thank the farmers for giving access to their flocks; the A.I.P.A./A.P.A.s (Provincial Farmers Associations) of Cagliari, Nuoro, Sassari, and Oristano (Italy) and the firms Sepi Formaggi (Marrubiu, Italy) and L'Armentizia Moderna (Guspini, Italy) for their support in sample collection; A.R.A. Sardegna (Regional Farmers Association of Sardinia) for support in chemical milk analysis.

\section{REFERENCES}

Ambrosoli, R., L. Di Stasio, and P. Mazzocco. 1988. Content of alphas1-casein and coagulation properties in goat milk. J. Dairy Sci. $71: 24-28$.

Attaie, R., and R. L. Richter. 2000. Size distribution of fat globules in goat milk. J. Dairy Sci. 83:940-944.

Banks, J. M. 2007. Cheese yield. Pages 100-114 in Cheese Problems Solved. P. L. H. McSweeney, ed. Woodhead Publishing Ltd., Cambridge, UK.

Bittante, G., C. Cipolat-Gotet, and A. Cecchinato. 2013. Genetic parameters of different measures of cheese yield and milk nutrient recovery from an individual model cheese-manufacturing process. J. Dairy Sci. 96:7966-7979.

Cecchinato, A., and G. Bittante. 2016. Genetic and environmental relationships of different measures of individual cheese yield and curd nutrients recovery with coagulation properties of bovine milk. J. Dairy Sci. 99:1975-1989.

Chen, S. X., J. Z. Wang, J. S. Van Kessel, F. Z. Ren, and S. S. Zeng. 2010. Effect of somatic cell count in goat milk on yield, sensory quality, and fatty acid profile of semisoft cheese. J. Dairy Sci. 93:1345-1354.

Cipolat-Gotet, C., A. Cecchinato, and G. Bittante. 2015. Phenotypic analysis of cheese yields and nutrient recoveries in the curd of buffalo milk, as measured with an individual model cheese-manufacturing process. J. Dairy Sci. 98:633-645.

Cipolat-Gotet, C., A. Cecchinato, M. De Marchi, and G. Bittante. 2013. Factors affecting variation of different measures of cheese yield and milk nutrients recovery from an individual model cheese manufacturing process. J. Dairy Sci. 96:7952-7965.

Cipolat-Gotet, C., A. Cecchinato, M. Pazzola, M. L. Dettori, G. Bittante, and G. M. Vacca. 2016b. Potential influence of herd and animal factors on the yield of cheese and recovery of components from Sarda sheep milk, as determined by a laboratory bench-top model cheese-making. Int. Dairy J. 63:8-17.

Cipolat-Gotet, C., A. Cecchinato, G. Stocco, and G. Bittante. 2016a. The 9-MilCA method as a rapid, partly automated protocol for simultaneously recording milk coagulation, curd firming, syneresis, cheese yield, and curd nutrients recovery or whey loss. J. Dairy Sci. 99:1065-1082

Clark, S., and M. B. Mora García. 2017. A 100-year review: Advances in goat milk research. J. Dairy Sci. 100:10026-10044. https://doi .org/10.3168/jds.2017-13287.

Damiàn, J. P., I. Sacchi, S. Reginensi, D. De Lima, and J. Bermúdez. 2008. Cheese yield, casein fractions and major components of milk of Saanen and Anglo-Nubian dairy goats. Arq. Bras. Med. Vet. Zootec. 60:1564-1569.

Emmons, D. B., C. Dube, and H. W. Modler. 2003. Transfer of protein from milk to cheese. J. Dairy Sci. 86:469-485.

Emmons, D. B., C. A. Ernstrom, C. Lacroix, and P. Sauve. 1993. Further considerations in formulae for predicting cheese yield from the composition of milk. J. Dairy Sci. 76:914-920.

Emmons, D. B., and H. W. Modler. 2010. Invited review: A commentary on predictive cheese yield formulas. J. Dairy Sci. 93:55175537.

Fagan, C. C., M. Castillo, F. A. Payne, C. P. O’Donnell, M. Leedy, and D. J. O'Callaghan. 2007. Novel online sensor technology for continuous monitoring of milk coagulation and whey separation in cheesemaking. J. Agric. Food Chem. 55:8836-8844.

FAOSTAT (Food and Agriculture Organization of the United Nations Statistics Division). 2014. Statistical Database of the Food and Agriculture Organization of the United Nations. Accessed Dec. 4, 2017. http://www.fao.org/faostat.

Fekadu, B., K. Soryal, S. Zeng, D. Van Hekken, B. Bah, and M. Villaquiran. 2005. Changes in goat milk composition during lactation and their effect on yield and quality of hard and semi-hard cheeses. Small Rumin. Res. 59:55-63.

Fox, P. F., T. P. Guinee, T. M. Cogan, and P. L. Mc Sweeney. 2000. Fundamentals of Cheese Science. Aspen Publishers Inc., Gaithersburg, MD.

Guo, M., Y. W. Park, P. H. Dixon, J. A. Gilmore, and P. S. Kindstedt. 2004. Relationship between the yield of cheese (Chèvre) and chemical composition of goat milk. Small Rumin. Res. 52:103-107.

Hallén, E., A. Lunden, T. Allmere, and A. Andren. 2010. Casein retention in curd and loss of casein into whey at chymosin-induced coagulation of milk. J. Dairy Res. 77:71-76.

Herrera, V., M. Chavez, M. F. Gonzáles, J. M. Quinteros, M. E. Ogas, and R. Páez. 2010. Milk quality and cheese yield of four European and African goat biotypes bred in a semi arid area of Argentina Northwest. Page 4 in Proceeding of 10th International Conference of Goats. Actas Iberoamericanas en Conservación Animal, Córdoba, Spain.

ISO-IDF (International Organization for Standardization and International Dairy Federation). 2010. Milk and liquid milk products. Determination of total solids content. International Standard ISO 6731 and IDF 21:2010a. ISO, Geneva, Switzerland, and IDF, Brussels, Belgium.

ISO-IDF (International Organization for Standardization and International Dairy Federation).2013. Milk and liquid milk products. Determination of fat, protein, casein, lactose and $\mathrm{pH}$ content. International Standard ISO 9622 and IDF 141:2013. ISO, Geneva, Switzerland, and IDF, Brussels, Belgium.

Janhøj, T., and K. B. Qvist. 2010. The formation of cheese curd. Pages 130-165 in Technology of Cheesemaking. B. A. Law and A. Y. Tamine, ed. Wiley-Blackwell, Ames, IA.

Kouniba, A., M. Berrada, and A. El Marakchi. 2007. Étude comparative de la composition chimique du lait de chèvre de la race locale Marocaine et la race alpine et évaluation de leur aptitude fromagère. Rev. Med. Vet. 158:152-160.

Law, B. A., and A. Y. Tamine, eds. 2010. Technology of Cheesemaking. 2nd ed. John Wiley \& Sons, Ltd., Chicester, UK.

Melilli, C., J. M. Lynch, S. Carpino, D. M. Barbano, G. Licitra, and A. Cappa. 2002. An empirical method for prediction of cheese yield. J. Dairy Sci. 85:2699-2704. 
Moatsou, G., M. Samolada, P. Panagiotou, and E. Anifantakis. 2004. Casein fraction of bulk milk from different caprine breeds. Food Chem. 87:75-81.

NRC. 2001. Nutrient Requirements of Dairy Cattle. 7th rev. ed. Natl. Acad. Press, Washington, DC.

Othmane, M. H., J. A. Carriedo, F. San Primitivo, and L. F. De La Fuente. 2002b. Genetic parameters for lactation traits of milking ewes: Protein content and composition, fat, somatic cells and individual laboratory cheese yield. Genet. Sel. Evol. 34:581-596.

Othmane, M. H., L. F. De la Fuente Crespo, J. A. Carriedo, and F. San Primitivo. 2002a. Heritability and genetic correlations of test day milk yield and composition, individual laboratory cheese yield, and somatic cell count for dairy ewes. J. Dairy Sci. 85:2692-2698.

Pazzola, M., M. L. Dettori, E. Pira, A. Noce, P. Paschino, and G. M. Vacca. 2014. Effect of polymorphisms at the casein gene cluster on milk renneting properties of the Sarda goat. Small Rumin. Res. 117:124-130.

Pazzola, M., G. Stocco, M. L. Dettori, C. C. Gotet, G. Bittante, and G. M. Vacca. 2018. Modeling of coagulation, curd firming, and syneresis of goat milk. J. Dairy Sci. https://doi.org/10.3168/jds 2018-14397.

Remeuf, F., V. Cossin, C. Dervin, J. Lenoir, and R. Tomassone. 1991. Relationships between physicochemical characteristics of milks and their cheese-making properties. Lait 71:397-421.

Soryal, K., F. A. Beyene, S. Zeng, B. Bah, and K. Tesfai. 2005. Effect of goat breed and milk composition on yield, sensory quality, fatty acid concentration of soft cheese during lactation. Small Rumin. Res. 58:275-281.

Stocco, G., C. Cipolat-Gotet, V. Gasparotto, A. Cecchinato, and G. Bittante. 2018. Breed of cow and herd productivity affect milk nutrient recovery in curd, and cheese yield, efficiency and daily production. Animal 12:434-444 https://doi.org/10.1017/ S1751731117001471.

Vacca, G. M., M. L. Dettori, G. Piras, F. Manca, P. Paschino, and M. Pazzola. 2014. Goat casein genotypes are associated with milk production traits in the Sarda breed. Anim. Genet. 45:723-731.

Vacca, G. M., P. Paschino, M. L. Dettori, M. Bergamaschi, C. CipolatGotet, G. Bittante, and M. Pazzola. 2016. Environmental, morphological and productive characterization of Sardinian goats and use of latent explanatory factors for population analysis. J. Anim. Sci. 94:3947-3957.

Vacca, G. M., G. Stocco, M. L. Dettori, E. Pira, G. Bittante, and M. Pazzola. 2018. Milk yield, quality and coagulation properties of six breeds of goats: Environmental and individual variability. J. Dairy Sci. https://doi.org/10.3168/jds.2017-14111.

Van Slyke, L. L., and W. V. Price. 1949. Cheese. rev. ed. Orange Judd Publ. Co., New York, NY.

Van Slyke, L. L., and C. A. Publow. 1910. The Science and Practice of Cheese Making. Orange Judd Company, New York, NY.

Zeng, S. S., K. Soryal, B. Fekadu, B. Bah, and T. Popham. 2007. Predictive formulae for goat cheese yield based on milk composition. Small Rumin. Res. 69:180-186. 